\title{
SPECTRUM OF BREAST PROBLEMS IN WOMEN: A HOSPITAL BASED STUDY IN MANIPUR
}

\author{
A. Ranjita Devi' ${ }^{1}$, N. Somorjit Singh'2, Tozo Luwang3, P. Kiran Singh ${ }^{4}$ \\ ${ }^{1}$ Assistant Professor, Department of Surgery, Jawaharlal Nehru Institute of Medical Sciences, Porompat, Manipur. \\ ${ }^{2}$ Associate Professor, Department of Surgery, Jawaharlal Nehru Institute of Medical Sciences, Porompat, Manipur. \\ ${ }_{3}^{3}$ Senior Resident, Department of Surgery, Jawaharlal Nehru Institute of Medical Sciences, Porompat, Manipur. \\ ${ }^{4}$ Senior Resident, Department of Surgery, Jawaharlal Nehru Institute of Medical Sciences, Porompat, Manipur.
}

ABSTRACT
BACKGROUND
Breast problem is one of the most common complaint in women of various age groups who attended Surgery Outpatient
Department (SOPD) in the Jawaharlal Nehru Institute of Medical Sciences, Porompat, Manipur (JNIMS). Although majority of them
had benign problems, diagnosis of a benign lesion from malignant lesion is important as breast cancer is the worst fear of a female
presenting with breast problems.

\section{AIM AND OBJECTIVE}

To describe various types of breast problems presented in Surgery OPD, JNIMS between September 2014 and April 2015.

\section{STUDY DESIGN}

A prospective descriptive study.

\section{SETTING}

Surgery OPD, JNIMS, Porompat, Imphal Manipur.

\section{METHOD}

Data including the age, sex, type of complaints, the clinical, radiological and histological diagnosis was obtained and recorded from all consecutive adult patients seen and treated at JNIMS, Porompat between Sept. 2014 and April 2015. All the participants were also interviewed about the knowledge of Self-Breast Examination (SBE) and asked to demonstrate. We recorded the numbers of patients who can demonstrate the correct method of Self-Breast Examination.

\section{RESULTS}

A total of 220 patients were studied. The age of the patients varied between 10 years and 73 years. Only 43 patients (19.5\%) could demonstrate the proper method of Self-Breast Examination and the rest 177 patients (80.4 \%) didn't know the method. The two most common complaints were breast pain-102 (46.3\%), breast lump-100 (45.4\%) and other miscellaneous conditions-18 $(8.1 \%)$ and most unfortunate 6 patients $(2.9 \%)$ were found with Carcinoma of Breast.

\section{CONCLUSION}

Breast pain \& breast lumps are the most common breast related problems presented in our SOPD. More widespread awareness and education about the different breast problems is required for better survival.

\section{KEYWORDS}

OPD, JNIMS, SBE, CBE, USG, FNAC.

HOW TO CITE THIS ARTICLE: Devi AR, Singh NS, Luwang T, et al. Spectrum of breast problems in women: A hospital based study in Manipur. J. Evolution Med. Dent. Sci. 2016;5(75):5520-5522, DOI: 10.14260/jemds/2016/1247

\section{INTRODUCTION}

Breast is a glandular organ influenced by hormones in females that results in changes throughout reproductive life. The consequences of breast problems besides creating anxiety can result in carcinoma which causes unbearable pain and deformity. The purpose of this study is to analyse various

Financial or Other, Competing Interest: None.

Submission 26-08-2016, Peer Review 08-09-2016,

Acceptance 10-09-2016, Published 16-09-2016.

Corresponding Author:

Dr. N. Somorjit Singh,

Associate Professor,

Department of Surgery,

Jawaharlal Nehru Institute of Medical Sciences,

Porompat, Manipur.

E-mail: drnssingh@yahoo.com

DOI: $10.14260 /$ jemds $/ 2016 / 1247$

(c) (i) breast problems in different age groups and to evaluate the histology of breast lumps, suspicious of malignancy in FNAC. Early diagnosis will help in better management of the case, reduce undue anxiety of the patients in benign cases and reduce morbidity and mortality.

\section{Inclusion Criteria}

All the symptomatic breast patients attended in the Surgery OPD who are willing to participate in the study.

\section{Exclusion Criteria}

1. Patients who are not willing to participate in the study.

2. Patients who are not co-operative.

\section{METHOD}

This is a prospective hospital based descriptive study conducted in the in the Jawaharlal Nehru Institute of Medical 
Sciences, Porompat, Manipur (JNIMS) between $1^{\text {st }}$ September, 2014 and 30th April, 2015.

The informed consent was taken from each participant and data collected regarding the personal information with the presenting complaints and findings.

\section{Patients were included in the study and were divided} into Three Groups

Group 1: Breast pain and discomfort.

Group 2: Breast Lump with/without palpable axillary Lymph Node.

Group 3: Other Misc. conditions (Lipoma, sebaceous cyst, etc).

All the patients with complaints of breast problems were evaluated by clinical history including a detailed history of the breast complaint presented, general physical examination and a clinical breast examination (CBE) along with the examination of the axilla and the supra and infraclavicular fossae for any palpable lymph nodes. All the participants were also interviewed about the knowledge of Self-Breast Examination (SBE) and asked to demonstrate. We recorded the numbers of patients who can demonstrate the correct method of SelfBreast Examination.

Then, the necessary investigations as required like Ultrasonography (USG) of the Breasts (Fig. 1), Fine Needle Aspiration Cytology (FNAC) (Fig. 2) and Excision Biopsy (Fig. 3 ) for the breast lumps were done to assess all breast masses.

The final diagnosis was made with the clinical findings along with specific Investigation of the breast and the histology of the lump.

Treatment was offered according to diagnosis made either simple excision or mastectomy accordingly. Regular followup was advised in 1 month and 3 months and yearly according to the disease pattern.

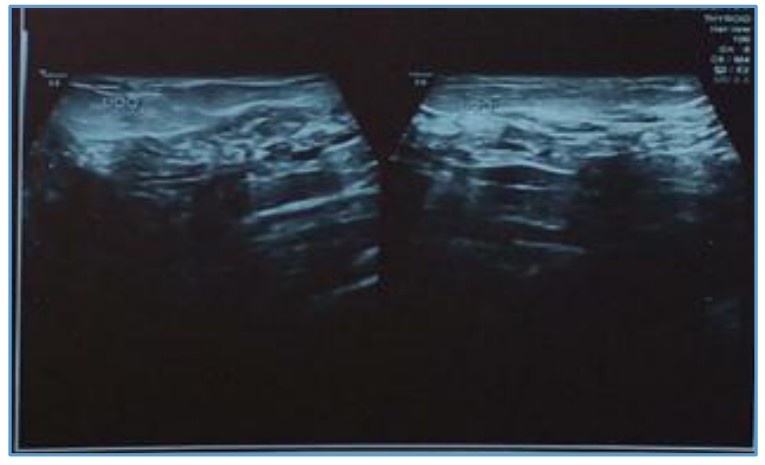

Fig. 1: Ultrasonography of Breast

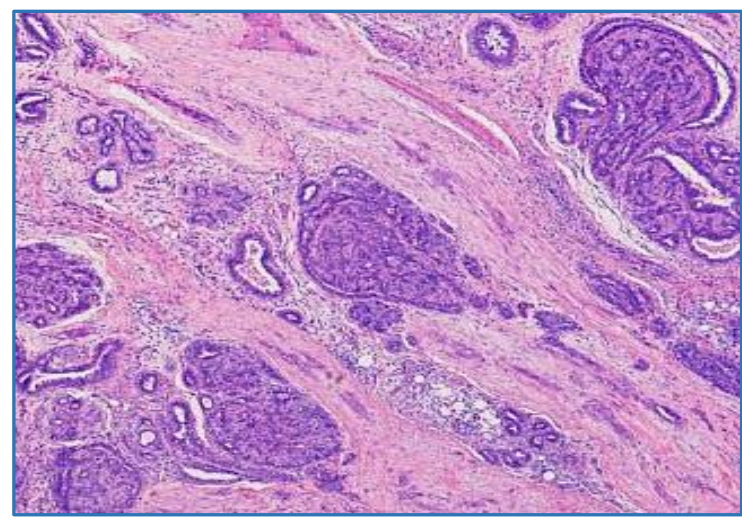

Fig. 2: FNAC indicating Adenocarcinoma of Breast

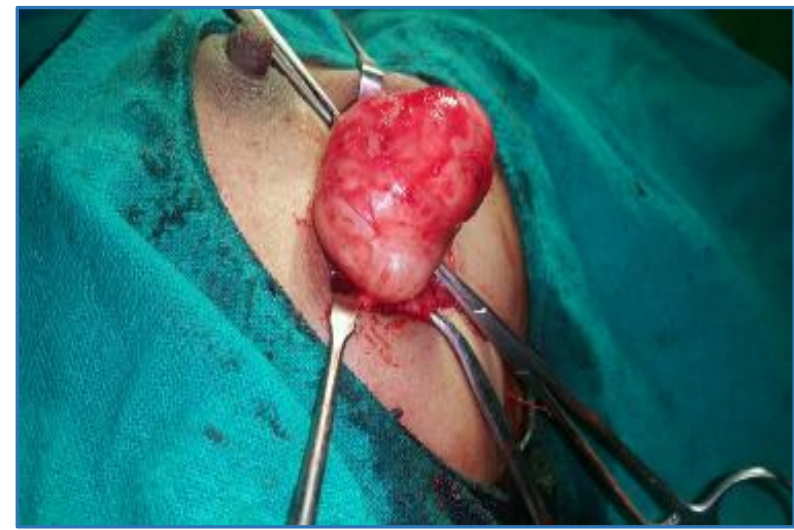

Fig. 3: Excision Biopsy of a Breast Lump

\section{RESULTS}

Two hundred and twenty patients were seen and treated at JNIMS Surgery Department. The age of the patients varied between 10 years and 73 years (Table 1). The peak age of incidence for breast pain was (31-40) years and that of breast lump was (21-30) years. Only 43 patients (19.5\%) could demonstrate the proper method of Self-Breast Examination and the rest 177 patients (80.4\%) didn't know the method.

\begin{tabular}{|c|c|c|c|}
\hline \multirow{2}{*}{$\begin{array}{c}\text { Age } \\
\text { (Years) }\end{array}$} & \multirow{2}{*}{$\begin{array}{c}\text { No. of } \\
\text { Patients }\end{array}$} & Yelf-Breast Exam (Yes/No) \\
\cline { 3 - 4 } & 28 & 7 & No \\
\hline $10-20$ & 66 & 16 & 21 \\
\hline $21-30$ & 70 & 4 & 50 \\
\hline $31-40$ & 34 & 6 & 66 \\
\hline $41-50$ & 18 & 6 & 28 \\
\hline $51-60$ & 2 & 2 & 12 \\
\hline $61-70$ & 2 & 2 & - \\
\hline $71-80$ & 220 & 43 & - \\
\hline \multicolumn{4}{|c|}{} \\
\hline \multicolumn{4}{|c|}{ Table 1: Relation with Age and Knowledge } \\
of Self-breast Exam (Yes/No) \\
\hline
\end{tabular}

The two most common complaints were breast pain-102 (46.3\%), breast lump-100 (45.4\%) and other miscellaneous conditions-18 (8.1\%). The duration of symptoms before presentation varied between 1 day to 3 years. The mean time interval between onset of symptoms and presentation at SOPD was 3 weeks and 4 months for breast pain, breast lump respectively (Table 2). The reasons for the delay in presentation for breast lumps were "painless" in 76 (75\%) patients, "might disappear with time" in $15(15 \%)$ patients and "waiting to see" in $10(10 \%)$ of the patients.

\begin{tabular}{|c|c|c|c|c|c|}
\hline $\begin{array}{c}\text { Sl. } \\
\text { No. }\end{array}$ & Symptoms & $\begin{array}{c}\text { No. of } \\
\text { Patients }\end{array}$ & $\%$ & $\begin{array}{c}\text { Time } \\
\text { Interval }\end{array}$ & Mean \\
\hline 1 & Breast Pain & 102 & $46.3 \%$ & $\begin{array}{c}1 \text { to } 30 \\
\text { Days }\end{array}$ & 21 Days \\
\hline 2 & $\begin{array}{c}\text { Breast } \\
\text { Lump }\end{array}$ & 100 & $45.4 \%$ & $\begin{array}{c}1 \text { to } 36 \\
\text { Months }\end{array}$ & $\begin{array}{c}4 \\
\text { Months }\end{array}$ \\
\hline 3 & $\begin{array}{c}\text { Other Misc. } \\
\text { Conditions }\end{array}$ & 18 & $8.1 \%$ & Variable & - \\
\hline \multicolumn{5}{|c|}{ Table 2: Duration of Symptoms } \\
\hline \multicolumn{6}{|c|}{} \\
\hline
\end{tabular}




\begin{tabular}{|c|c|c|c|}
\hline $\begin{array}{c}\text { Sl. } \\
\text { No. }\end{array}$ & Diagnosis & $\begin{array}{c}\text { No. of } \\
\text { Patients }\end{array}$ & Percentage \\
\hline 1 & $\begin{array}{c}\text { Normal Breast } \\
\text { (With Breast Pain) }\end{array}$ & 64 & $31.6 \%$ \\
\hline 2 & Mastitis & 38 & $18.8 \%$ \\
\hline 3 & Fibroadenoma & 80 & $39.6 \%$ \\
\hline 4 & Fibroadenosis & 20 & $9.9 \%$ \\
\hline 5 & Carcinoma & 6 & $2.9 \%$ \\
\hline 6 & Abscess & 4 & $1.9 \%$ \\
\hline \multicolumn{3}{|c|}{ Table 3: Final Diagnosis in 202 patients (Group 1 and } \\
Group 2) based on the Clinical Exam, and \\
Histopathology Report \\
\hline \multicolumn{4}{|c|}{} \\
\hline
\end{tabular}

\begin{tabular}{|c|c|c|}
\hline $\begin{array}{c}\text { Sl. } \\
\text { No. }\end{array}$ & Diagnosis & $\begin{array}{c}\text { No. of } \\
\text { Patients }\end{array}$ \\
\hline 1. & Breast Lipoma & 2 \\
\hline 2. & Mondor's Disease & 1 \\
\hline 3. & Breast Sebaceous Cyst & 1 \\
\hline 4. & Galactocoele & 7 \\
\hline 5. & Duct Ectasia & 2 \\
\hline 6. & Hypertrophied Scar & 1 \\
\hline 7. & Injury & 2 \\
\hline 8. & Skin Conditions & 2 \\
\hline \multicolumn{3}{|c|}{ Table 4: Miscellaneous Diagnosis } \\
in 18 patients (Group 3) \\
\hline
\end{tabular}

Out of the 220 Patients, 202 patients (Group 1 and Group 2) had breast pain with normal breast-64 (31.6\%), breast pain with mastitis 38 (18.8\%), fibroadenomas 80 (39.6\%), fibroadenosis-20 (9.9\%), carcinoma-6 (2.9\%), breast abscess-4 (1.9\%). The other miscellaneous group (Group 3) had 18 patients with other benign conditions as Lipoma, Cyst, Duct ectasia, etc. as shown in Table 4.

\section{DISCUSSION}

Majority of the women seen at the JNIMS, SOPD were young and complained mostly of breast pain and breast lump. The spectrum of breast problems in our study is similar to that reported in other series.[1,2,3] The relative proportion of benign disease; however, may vary from populations. [3,1]

Previous studies from general surgical clinics and specialist breast centres have reported similar results. $[4,1,2,5]$ Breast pain causes considerable morbidity and anxiety worldwide.[5,6] The results of various clinical trials in Europe, America and Asia have provided some data to guide clinicians treating women with breast pain.

Previous studies that have investigated the relation between breast cancer and breast pain from various populations have reported variable results. Duigin and coworkers reported that cancer was detected in only $0.4 \%$ of patients having mammography for breast pain with no other symptoms.[7] Mansel in a review of breast pain stated that only $7 \%$ of patients with cancer have mastalgia as the only symptom. ${ }^{[8]}$ Preece et al found that $15 \%$ of patients with operable cancer had pain as one of the presenting symptoms.(9) A study on mastalgia and breast tumour in Nigerian women reported that $8.3 \%$ of patients with histologically proven malignant breast tumour had pain in addition to breast lump.[10]

In our study, among the women presenting with breast pain only, no palpable lump was found clinically, and also no lump detected in ultrasonography of the breasts. These women attended in the hospital with the apprehension of possible breast diseases. But almost all the women having breast lump detected by themselves and also confirmed by clinical examination in the hospital has the fear psychosis of having breast cancer. Out of the total 220 patients, majority were benign conditions diagnosed by FNAC and Histopathology. Only 6 patients $(2.9 \%)$ with a well-defined lump were confirmed as breast cancer which can be detected much earlier and treated at the early stage. This delay in reporting to the hospital with breast lumps as compared with breast pain reported in our study determines that many women consider painless breast lumps as harmless, as well there is lack of awareness and education of the breast disease including Self-Breast Examination.

\section{CONCLUSION}

Breast pain and Breast lump are the two most common complaints in patients reporting at our SOPD in JNIMS. Breast Problem is so common that out of the total registered women patients in SOPD for consultation it was in the ratio of 1:16. They often reported late to the doctor for consultation in spite of the risk of a breast cancer diagnosis at their first visit. So, in addition to the present status about the breast health awareness and education, more large scale health education programs aimed at effectively informing the public on the breast cancer risks are needed.

\section{REFERENCES}

1. Ihekwaba FN. Benign breast disease in Nigerian women: a study of 657 patients. J R Coll Surg Edin 1994;39(5): 280-3.

2. Khanna R, Khanna S, Chaturvedi S, et al. Spectrum of breast disease in young females: a retrospective study of 1315 patients. Indian J Pathol Microbiol 1998;41(4):397401.

3. Asuman R, Vowotor R, Naaedar SB. Pattern of breast disease in Ghana. Ghana Med J 2000;34(4):206-9.

4. Cox PJ, Li MK, Ellis H. Spectrum of breast disease in outpatient surgical practice. J Roy Soc Med 1982;75(11): 857-9.

5. Leinster SJ, Whitehouse GH, Walsh PV. Cyclical mastalgia: clinical and mammography observations in a screened population. Br J Surg 1987;74(3):220-2.

6. Prance SE, Pass HA. Etiology and management of breast pain. In: Singletary SE, Robb GL, Hortobagy GN, eds. Advance therapy of breast disease. $2^{\text {nd }}$ edn. London: BC Becker 2004:25-36.

7. Dujim LE, Guit GL, Hendriks JH, et al. Value of breast imaging in women with painful breasts: observational followup study. Br Med J 1998;317(7171):1492-5.

8. Mansel RE. The abc of breast disease. Breast pain. BMJ 1994;309(6958):866-8.

9. Preece PE, Baum M, Mansel RE, et al. Importance of mastalgia in operable breast cancer. BMJ (Clin Res Ed) 1982;284(6325):1299-300.

10. Chiedozie LC, Guirguis MN. Mastalgia and breast tumour in Nigerian women. West Afr J Med 1990;9(1):54-8. 